\title{
KORSZERÛ HEGESZTÉS TECHNOLÓGIA A HÁZTARTÁSI GÉPEK GYÁRTÁSÁHOZ
}

\section{MODERN WELDING TECHNOLOGY FOR HOUSEHOLD PRODUCTS MANUFACTURING}

\author{
Pop-Szováti Antal György ${ }^{1}$, Gyenge Csaba ${ }^{2}$, Borzan Marian ${ }^{3}$ \\ ${ }^{1}$ Electrolux, Románia, Szatmárnémeti (Satu-Mare), Calea Traian nr.28-29. \\ anton_pops@yahoo.com \\ ${ }^{2,3}$ Kolozsvári Müszaki Egyetem, Gépészmérnöki Kar, Gépgyártástechnológiai Tan- \\ szék, 400184, Románia, Kolozsvár, B-dul Muncii nr.103-105. \\ ${ }^{2}$ Csaba.Gyenge@tcm.utcluj.ro, ${ }^{3}$ Marian.Borzan@tcm.utcluj.ro
}

\begin{abstract}
In Electrolux - Satu-Mare (RO) they are manufacturing a wide range of cookers on gas, electric, induction and mixed. Today the automation and robotized manufacturing of competitive product has an important role in the series production of cooking machines. For the manufacturing of semi-finished products for different types of cookers on the same manufacturing line, robotic or automated, flexibility is needed. The welding operation on a computer-assisted assembly line can't be separated by the actuators electrical, mechanical, pneumatic and hydraulic which alternate in perfect synchronization. This paper present the specific achievements with regard to the flexibility on an assembly line through welding of semi-finished products.
\end{abstract}

Keywords: welding, technology, assembly, household, products.

\section{Összefoglalás}

A szatmárnémeti Electrolux különböző gázzal, valamint villanyárammal üzemelő, kombinált tűzhelyek, illetve kerámialapos és indukciós konyhatüzhelyek gyártására szakosodott. Napjainkban a háztartási gépek versenyképes sorozatgyártásában fontos szerepe van az automatikának és a robotikának. A konyhatüzhelyek automatizált és a robotizált alegységek gyártási folyamatában rugalmasságra van szükség. Mivel a robotizált és automatizált gépsorok számítógépes vezérléssel müködnek, ahol a mechanikus, pneumatikus és hidraulikus meghajtások váltják egymást, ezek tervezését a korszerü hegesztési műveletek sajátosságait figyelembe véve kell végezni.

Kulcsszavak: hegesztés, sorozatgyártás, robotizálás, automatizálás, háztartási gépek.

\section{A szatmárnémeti Electrolux gyár történelmének rövid áttekinté- se}

A jelenlegi gyár területén, a Princz testvérek által 1906-ban alapított gyárban vas- öntés és gépgyártás folyt. A Princz mühelyekben mezőgazdasági, malomipari gépeket és alkatrészeket gyártottak. 1921-től mozdonyokat és vagonokat javítottak, a második világhaború ideje alatt tankokhoz és hadifelszerelésekhez szükséges alkatrészeket gyártottak. Az 1948-as államosítás- 
kor Szeptember 1 nevet kapta a gyár ahol ezután préselt és zománcozott termékeket gyártottak.

A privatizáció után, Samus részvénytársaság néven gyártottak gáztüzhelyeket, szilárd és folyékony üzemanyagos tüzhelyeket, vízmelegítőket és kazánokat, gázkonvektorokat, páraelszívókat.

Az Electrolux Csoport 1997-ben egy döntő erejü (99,52\%-os) részvénycsomagot vásárolt meg a dolgozók tulajdonában lévő részvényekből, így főrészvényessé vált.

A cég átvétele után számos módosításra és korszerüsítésre volt szükség.

Az új, korszerü háztartási gépek gyártásához szükséges részegységek előállításához, a tehnológiai folyamatok típusa szerint, a következő föbb szakosított gyártórészlegekre lett átszervezve: lemezdarabolás, képlékényalakítás, lemeztisztítás, festőde, zománcoló, öntvény- és alumíniumöntöde, galvanizáló és nikkelező. Minden szükséges részegységet ma a cégen belül gyártanak.

A gyár a belváros területén müködik, így számos környezetvédelmi feltételeknek kell megfelelnie: rezgés és zaj kibocsájtás, káros anyagok kibocsájtásának csökkentése vagy megszüntetése [1-4].

Ezzel párhuzamosan, szükségessé vált a munkakörülményekre vonatkozó Európa Uniós feltételek biztosítása.

Megszüntették a gyenge profitot hozó, környezet szennyező, és munkahelyi megbetegedéseket okozó vasöntődét.

Viszont, igen szükségessé vált és komoly programok indultak a szerelési müveletek automatizálása és robotizálása érdekében [2-5].

A dolgozat keretén belül a gyártósoron végzett, gyártási műveletek automatizálásait igyekszünk bemutatni.

\section{A ponthegesztés és vonalhegesz- tés szerepe a konyhatüzhelyek gyártásában}

A gáztüzhelyek döntőrésze fém lemezlapokból van előállítva, így a részegységek összeillesztéséhez a ponthegesztést és vonalhegesztést alkalmazzuk (1. ábra).

Az előkészített lemezeket a hegesztendő helyen két, rendszerint kúpos áramvezető szerszám szorítja egymáshoz. Az összeszorított lemezeket az átfolyó áram felhevíti, azok pedig az átmeneti ellenállás felületén megolvadnak, az elektródákkal kifejtett erő hatására a lemezek, az elektródák átmérőjének megfelelő felületen, összeforrnak.

A vonalhegesztés a ponthegesztés elvén müködik, de áramvezetőként nem kúpos nyomószerszámot, hanem csapágyazott és hajtott görgőpárt használunk.
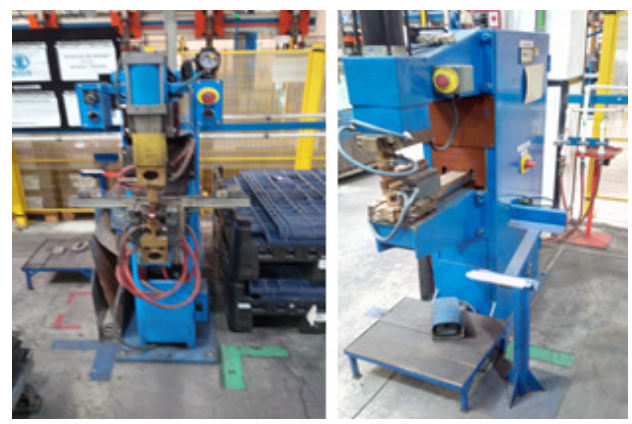

1. ábra. Ponthegesztö készülék munkaterülete

\section{A konyhatűzhelyek sütő rész- egységének automatizált és robotizált gyártási folyamata}

A konyhatüzhelyek gyártásában a sütő részegységként kerül a szerelőszalagra. Ezt darabolás, préselés, hideghegesztés és zománcolás folyamatai előzik meg, amelyek különböző termelési részlegeken zajlanak (2. ábra).

A sütők elektromos árammal vagy gázzal müködnek és önálló vagy aláépíthetö, multifunkciós, katalitikus illetve pirolítikus tisztítású berendezéssel vannak ellátva. 


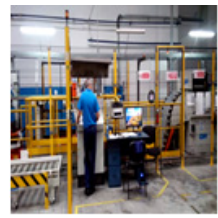

a)

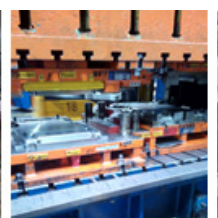

b)

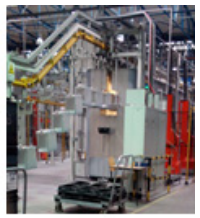

c) 2.ábra. Háztartási tüzhelyek gyártása a szatmárnémeti Electroluxban: a) daraboló részleg b) keplékenyalakitó részleg c) zománcoló részleg

A csoportunk, a különféle tüzhelyek részegységeinek előállítása céljából, egy új technológiai folyamatot dolgozott ki. A fejlesztés keretében kidolgozott alkalmazott számítógépes vezérlésü robotizált és automatizált hegesztési vonalon különböző típusú sütőket lehet rugalmasan előállítani.

A dolgozat keretében, igyekszünk ismertetni az automatizálás és robotizálás érdekében elért eredményeinket.

Az új gyártási vonal berendezésének, a tüzhelyek sütő részegységének hegesztéssel való előállításához, a következő követelményeknek kellett megfelelnie:

- a berendezés a lehető legkisebb területet igényelje;

- a különböző terméktípusok rugalmas változtatását megengedje;

- $\quad$ nagy termelékenység biztosítása;

- a karbantartási költségek a lehető legalacsonyabbra csökkentése;

- a vonalhegesztési müveleteket, energiatakarékosabb ponthegesztési müveletekkel helyettesítse.

\section{A konyhatüzhely sütőjének gyártási folyamata}

A konyhatűzhely két fö részből tevődik össze: a téglalap alakúra hajlított köpeny és a hasonló alakú lemezlap. Ezeket ponthegesztéssel rögzítik. A téglatest-keret hátsó oldalát fenéklap zárja, a másik oldalára ajtó van szerelve. A tüzhely típusától függően,

különböző nyílásokat, furatokat készítenek amelyek az égők, ellenállások, érzékelők, légkeverők, grillezők elhelyezésére szolgálnak. Azonos gépsoron, robotizált és automatizált gyártóvonalon, kisebb költséggel, jobb minőséget lehet elérni a konyhatüzhelyek és különböző típusú sütők összeállításában.

A hegesztő gyártóvonal Global típusú és ezért a kifejlesztett projektet, Global projektnek neveztük. A Global elnevezés a gépsor rugalmasságára vonatkozik.

A hegesztő gépsorhoz a leszabott lemezek elővágott csomagban érkeznek. Egy vákuummal müködő kar adagolja ezeket a présgének, amely a lemezlapot precíziós vágással kalibrálja.

A továbbiakban egy kamera felismeri a kombinációt és ennek alapján, az intelligens követö rendszer meghatározza a típusnak megfelelö későbbi müveleteket (3. ábra).

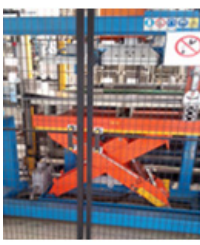

a)

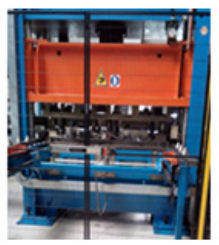

b)

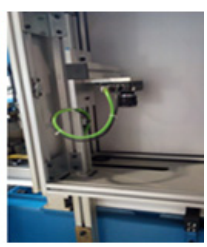

c)

3. ábra. $A$ sütő gyártásának müveletei: a) az adagoló szerkezet, b) vágószerszámos lemezlap kalibrálása, c) lyukasztás kombinációt felismerö kamera

A lemezlap téglalap alakú kerete a hajlítási részlegen valósul meg. Ezt követi a keret összerögzítése ponthegesztéssel az utána jövő részlegen (4. ábra).

A következő részlegen a tüzhely keretére dombornyomással, bordázással és lyukasztással kerülnek alakításra a különböző felületek. 


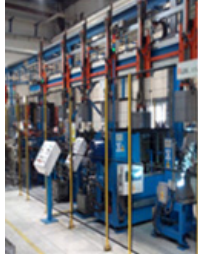

a)

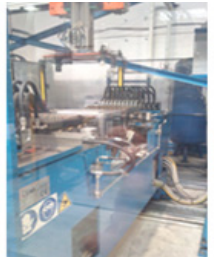

b)

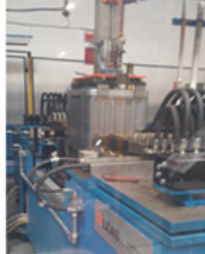

c)
4. ábra. Ponthegesztési müveletek részlege a gépsoron: a) müvelet váltás, b) hegesztési müvelet, c) munkadarab kiemelése

A fenéklapot a présgépek részlegéről tárolókosarakban szállítják és egy futószalag segítségével adagolják a hegesztővonal munkaterületére. Itt a fenéklapot két ponthegesztő gépen rögzítik a sütő keretéhez. Miután a munkadarab elkészült, zsírtalanítják, zománcolják majd a szerelö részlegre szállítják.

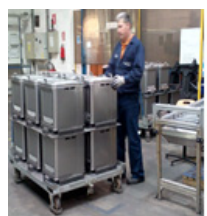

a)

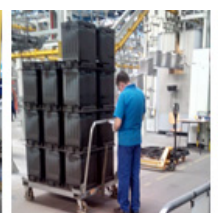

b)

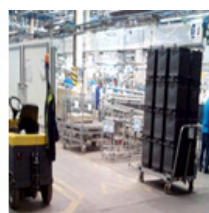

c)
5. ábra. Konyhatüzhelyek gyártási részlegei: a)ponthegesztéssel elöállitott végtermék, b)-zomancoló részleg, $\boldsymbol{c}$ )-szerelöszalag

\section{Következtetések}

A korszerü konyhatüzhelyek gyártásához komplex konstrukciójú gépsorvonalak szükségesek, amelyek jól meghatározott technológiai és müködési feltételeknek kell megfelelniük. Csoportunk, igyekezett megfelelő programozással és beállítással, rugalmasságot és magas termelékenységet biztosítani a különböző konyhatüzhelyek részegységeinek gyártásánál.
A jelenlegi gépsor fejlesztéséhez lehetőség van egy présgép csatolására, amely bisztosítja a sütő fenéklemez előállítását és adagolását a közvetlen technológiai folyamatban [3]. A továbbiakban a gyártásában egyre összetetebb termékek versenyképes előállítása érdekében, csoportunkra újabb követelmények hárulnak, amelyeket alapos elméleti és technológiai kutatásokkal kell megvalósítsunk.

\section{Szakirodalmi hivatkozások}

[1] Pop, A.; Gyenge, Cs.; Borzan, M.: Dynamic analyisis of vibration and noise metal forming presses, Debreceni müszaki közlemények 2014/2.

[2] Pop, A., Gyenge, Cs, Borzan, M.: Specific achievements in the direction of the automated assembly through adhesion of household machines, ANNALS of Faculty Engineering Hunedoara-International Journal of Engineering, Tome XIII [2015]- Fascicule 4 [November] ISSN:1584-2673.

[3] Pop, A., Gyenge, Cs, Borzan, M.: The study of mechanical presses drives using cold plastic deformation, Proceedings of the 3 rd International Scientific Conference on Advances in Mechanical Engineering (ISCAME 2015) 19 November, 2015 Debrecen, Hungary.

[4] Gyenge, Cs., Roş, O., Frăţilă, D., Varga, A.: Achievements of the Manufacturing Engineering Department from T.U. Cluj-Napoca in the Field of Competitive and Ecological Products Development. Conference on Environmental Engineering, May, 22nd-23rd, 2002, Košice, ISSN 1335-2393, p. 43- 49.

[5] Cs. Gyenge, N. Bâlc, P. Berce: Assembly with Robots of the Straight Way Valves, IEEE Proceedings of the 5th International Workshop on Robotics in Alpe-Adria Region RAAD'96, pag. 283-288, Budapest, June 1996, Hungary, ISBN 9634204821. 